\title{
Site Systems Engineering Fiscal Year 1999 \\ Multi-Year Work Plan (MYWP) Update for WBS 1.8.2.2
}

Date Published

September 1998

Prepared for the U.S. Department of Energy

Assistant Secretary for Environmental Restoration

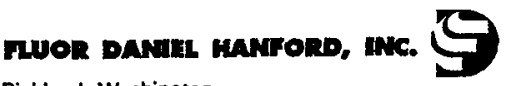

Richland, Washington

Hanford Management and Integration Contractor for the

U.S. Department of Energy under Contract DE-ACO6-96RL13200

Approved for Public Release; Further Dissemination Unlimited 


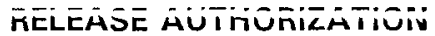

Document Number: HNF-SP-1239, Revision 1

Document Title: Work Plan (MYWP) Update for WBS 1.8.2.2

This document, reviewed in accordance with DOE Order 1430.1D, "Scientific and Technical Information Management," and DOE G 1430.1D-1, "Guide to the Management of Scientific and Technical Information," does not contain classified or sensitive unclassified information and is:

APPROVED FOR PUBLIC RELEASE

Y.Z.
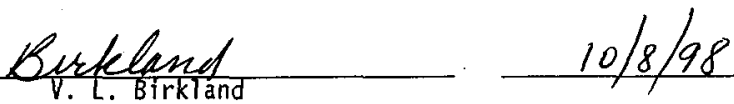

Lockheed Martin Services, Inc. Document Control/Information Clearance

Roviewed for Applied Tochnalogy, Butiness Sentitive, Clossified, Copyrighted, Export Controlled, Patent, Personel/Private, Propriotary, Protoctod CRADA. Tradomark, Unclatsified Controllod Nuclear Information.

LEGAL DISCLAIMER. Thle report was prepared as an eccount of work eponsored by an agoncy of the Unitod States Gavernment. Nelther the United States Govermment nor any agency thersof. not any of their employees, nor any of their contractors, tubcontractors or their employees, makes sny werrenty, express or implied. or assumes any legal liability or responsibility for the accuracy. completenest, or any third party's use or the resulte of euch use of any information, apparatus, product, or process disclosed, or represents that its use would not infringe privately owned rights. Reforence herein to any specific commercial product, process, or service by trade name, trademark, manufacturer, or otherwise, does not necess arily constitute or imply its endorsement. rocommendation, or favoring by the United States Govemment or any agency thereof or its contrectors or subcontractork. The viowe and opinions of authors expressed herein do not necessarily stato or seflect those of the United States Government or any ageney thereof. This roport has boen reproduced from the best available copy. Printed in the United States of Amorics. Available to the U.S. Department of Energy and its contractors from the U.S. Department of Energy Otfice of Scientific and Technical Information, P.O. Box 62. Oak Ridoe. TN 37831: Telephone: 423/576-8401.

Available to the public from the U.S. Department of Commerce National Technical information Sorvice, 5285 Port Royal Rosd, Springfleld, VA 22161: Telephone: 703/487-4650. 


\section{INFORMATION CLEARANCE FORM}

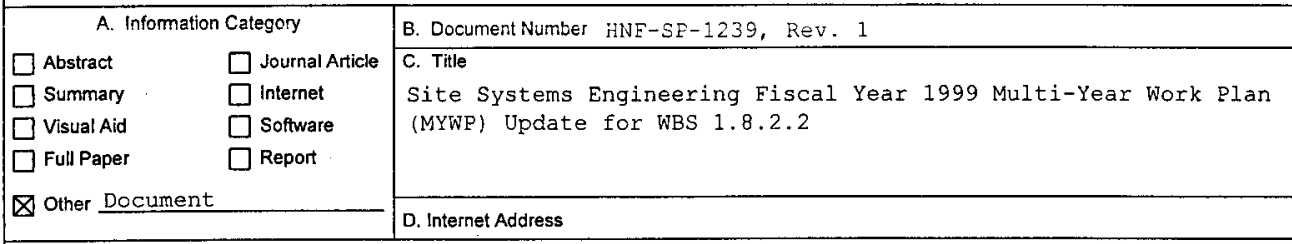

\section{E. Required information}

1. Is document potentially Classified? ONo OYes.(MANDATORY)

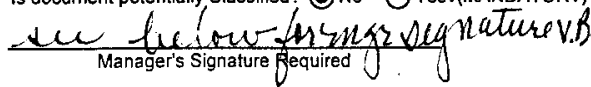

If Yes ADC Signature Required

2. Internal Review Required? If Yes, Document Signatures Below Ono OYes classified

Ono OYes

Counsel

Program

3. References in the Information are Applied Technology Export Controlled Information

Ono Ores Ono Ores
4. Does Information Contain the Following: (MANDATORY) a. New or Novel (Patentable) Subject Matter? ONo OYes

If "Yes", Disclosure No.:

b. Information Received in Confidence. Such as Proprietary and/or Inventions?

No OYes if "Yes", Affix Appropriate Legends/Notices.
c. Copyrights?
ONo OYes
If "Yes", Attach Permission.
d. Trademarks?
Ono OYes
If "Yes", Identify in Document.

5. Is Information requiring submission to OSTI? $\bigcirc$ No $\bigcirc$ Yes If Yes UC- 900 and $B \& R-Y / 10100100$

6. Release Level? $\bigcirc$ Public $\bigcirc$ Limited $H$

7. Charge code CACN:-106982 COA:AA30

F. Complete for a Journal Article

1. Title of Journal

G. Complete for a Presentation

1. Title for Conference or Meeting

2. Group Sponsoring

3. Date of Conference

5. Will Information be Published in Proceedings? $O$ No $\bigcirc$ Yes

4. City/State

H. Author/Requestor

6. Will Material be Handed Out?

Ono OYes
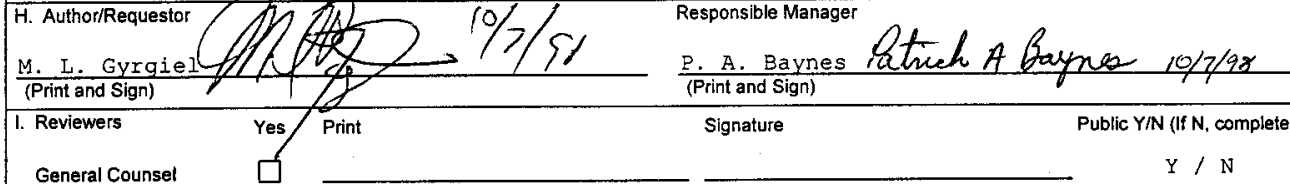

Signature

Public Y/N (If N, complete J)

General Counsel

$\mathrm{Y} / \mathrm{N}$

Office of External Affairs

DOE-RL

$\mathrm{Y} / \mathrm{N}$

Other

Other
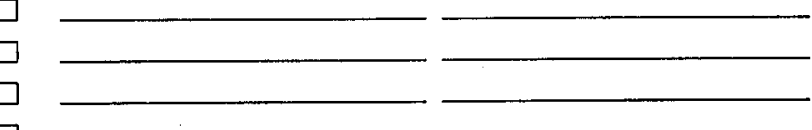

$\mathrm{Y} / \mathrm{N}$

$\mathrm{Y} / \mathrm{N}$

$\mathrm{Y} / \mathrm{N}$

J. If Information Includes Sensitive Information and is not to be released to the Public indicate category below.
$\square$ Applied Technology
$\square$ Protected CRADA
$\square$ PersonaVPrivate
$\square$ Export Controlled
$\square$ Proprietary
$\square$ Procurement-Sensitive
$\square$ Business-Sensitive
$\square$ Patentable
$\square$ Predecisional
Other (Specify)
$\square$ UCN

K. If Additional Comments, Please Attach Separate Sheet

Information Clearance Approval 


\section{Systems Engineering}

WBS 1.8.2.2

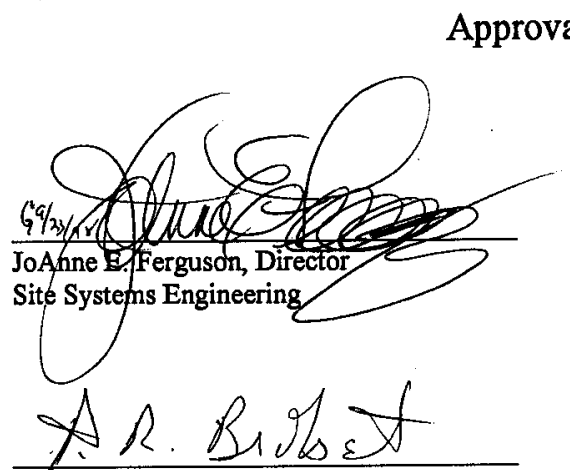

Phillip R. Brobst, Director

Site Planning and Integration

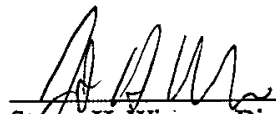

Steyen $\mathrm{H}$. Wisness, Director

Ppoject Management Division

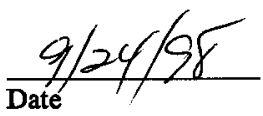

$\frac{9 / 25 / 98}{\text { Date }}$

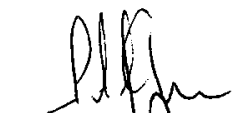

Peter M. Knollmeyer, Assistant Manager

For Facility Transition

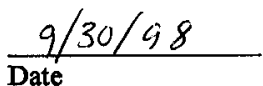

$\frac{7 / 30 / 96}{\text { Date }}$ 


\section{TABLE OF CONTENTS}

I. SUMMARY SECTION

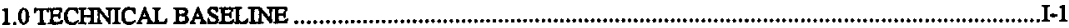

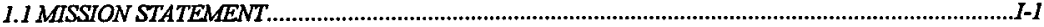

1.2 BOUNDARY DIAGRAM WITH MAJOR FACILITY ........................................................................

1.3 FACILITY RESPONSIBILITY ASSIGNMENT MATRLX

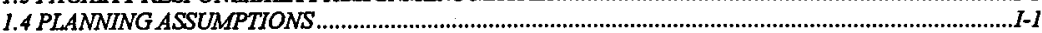

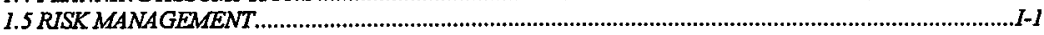

1.6 TECHINICAL ISSUES MANA GEMENT LIST (TZML) .......................................................................

2.0 PROJECT HANFORD BREAKDOWN STRUCTURE

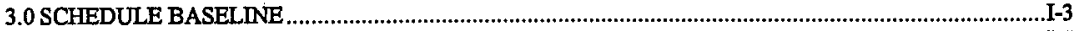

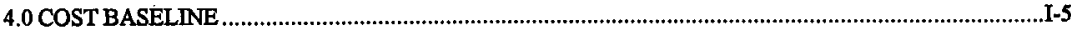

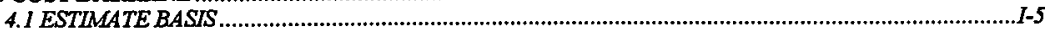

4.2 SUMMARY OF LIFE CYCLE COSTS BASELINE (BCWS) BY PROJECT …......................................

4.3 SUMMARY OF LIFE CYCLE BUDGET AUTHORITY (B/A) BY PRQJECT .....................................

4.4 COST BASELINE (BCWS) FOR EXECUTION YEAR BY MONTH BY FUND TYPE...........................I-5

4.5 COST BASELINE (BCWS) FOR EXECUTION BY MONTH BY RESOURCE TYPE................................

II. PROJECT BASELINE SUMMARIES (PBS) LEVEL

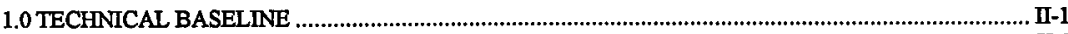

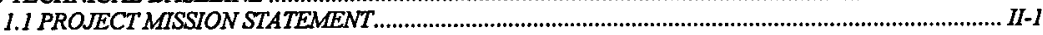

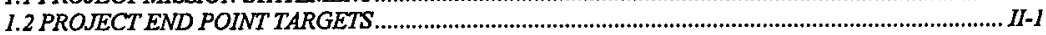

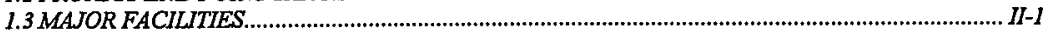

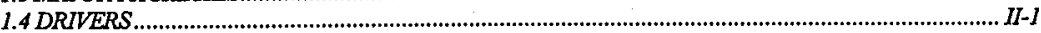

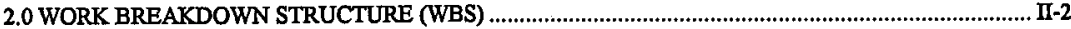

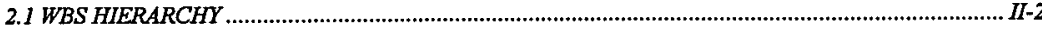

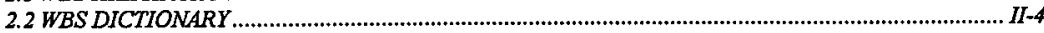

2.3 RESPONSIBILITY ASSIGNMENT MATRLX RAM) ..................................................................II-I0

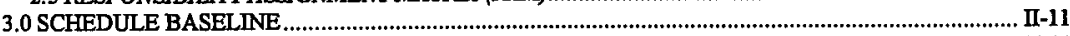

3.1 PROJECT MASTER BASELINE SCHEDULE (PMBS) BY PBS..................................................11

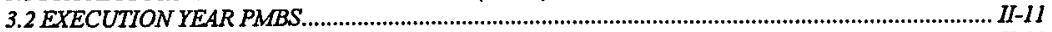

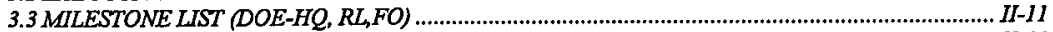

3.4 MILESTONE DESCRIPTION SHEETS MDS)............................................................................. II-11

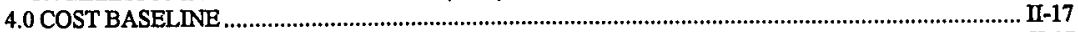

4.1 LIFE CYCLE COST BASEIINE (BCWS) BY PBS ...................................................................II-17

4.2 LIFE CYCLE BUDGET AUTHORITY (B/A) BY PBS .............................................................II-17

4.3 EXECUTION YEAR COST BASELINE BYMONTH BY PBS BY FUND TYPE …............................... II-17

II. ADDITIONAL REQUIREMENTS

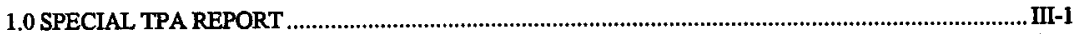

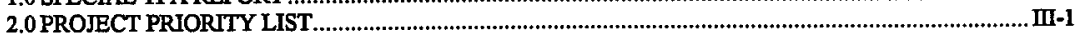

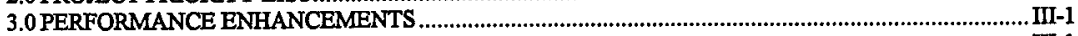

4.0 PERFORMANCE OBJECTIVES AND MEASURES.............................................................................

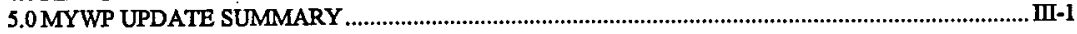




\section{SUMMARY SECTION}

\subsection{TECHNICAL BASELINE}

\subsection{MISSION STATEMENT}

Manage the Site Systems Engineering process to provide a traceable, integrated, requirements-driven, and technically defensible baseline. Through the Site Integration Group(SIG), Systems Engineering ensures integration of technical activities across all site projects. Systems Engineering's primary interfaces are with the RL Project Managers, the Project Direction Office and with the Project Major Subcontractors, as well as with the Site Planning organization. Systems Implementation:

- Develops, maintains, and controls the site integrated technical baseline, ensures the Systems Engineering interfaces between projects are documented, and maintain the Site Environmental Management Specification.

- Develops and uses dynamic simulation models for verification of the baseline and analysis of alternatives.

- Performs and documents functional and requirements analyses

- Works with projects, technology management, and the SIG to identify and resolve technical issues

- Supports technical baseline information for the planning and budgeting of the Accelerated Cleanup Plan, Multi-Year Work Plans, Project Baseline Summaries as well as performance measure reporting.

- Works with projects to ensure the quality of data in the technical baseline.

- Develops, maintains and implements the site configuration management system.

\subsection{BOUNDARY DIAGRAM WITH MAJOR FACILITY}

This site-prescribed section of the Multi-Year Work Plan does not apply to this project.

\subsection{FACILITY RESPONSIBILITY ASSIGNMENT MATRIX}

This site-prescribed section of the Multi-Year Work Plan does not apply to this project.

\subsection{PLANNING ASSUMPTIONS}

- RDD-100 will be deployed site wide and used as the standard for the technical baseline.

\subsection{RISK MANAGEMENT}

This site-prescribed section of the Multi-Year Work Plan does not apply to this project.

\subsection{TECHNICAL ISSUES MANAGEMENT LIST (TIML)}

This site-prescribed section of the Multi-Year Work Plan does not apply to this project. 
2.0 PROJECT HANFORD BREAKDOWN STRUCTURE

FY 1999

EM PROJECT HANFORD BREAKDOWN STRUCTURE

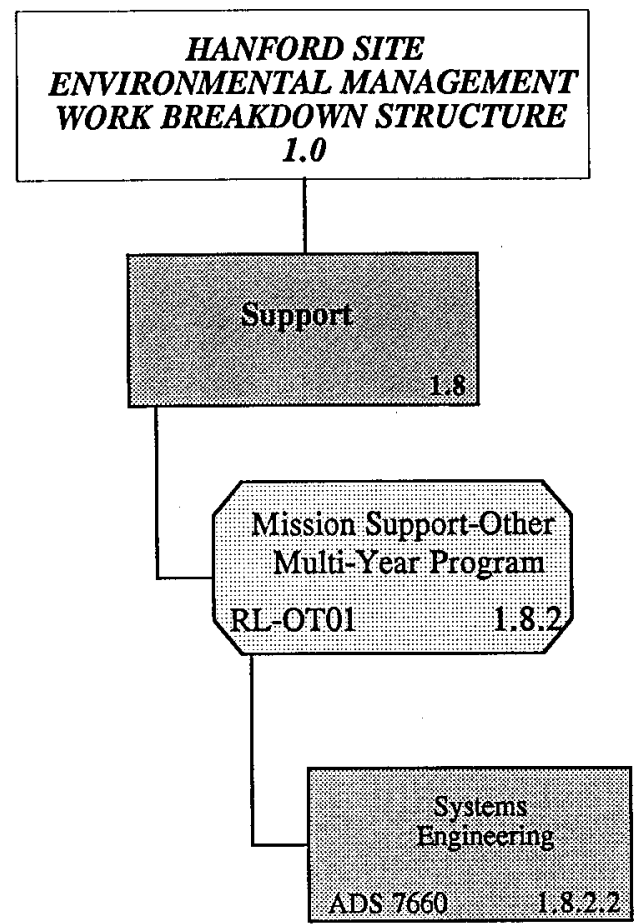


3.0 SCHEDULE BASELINE

See next page. 


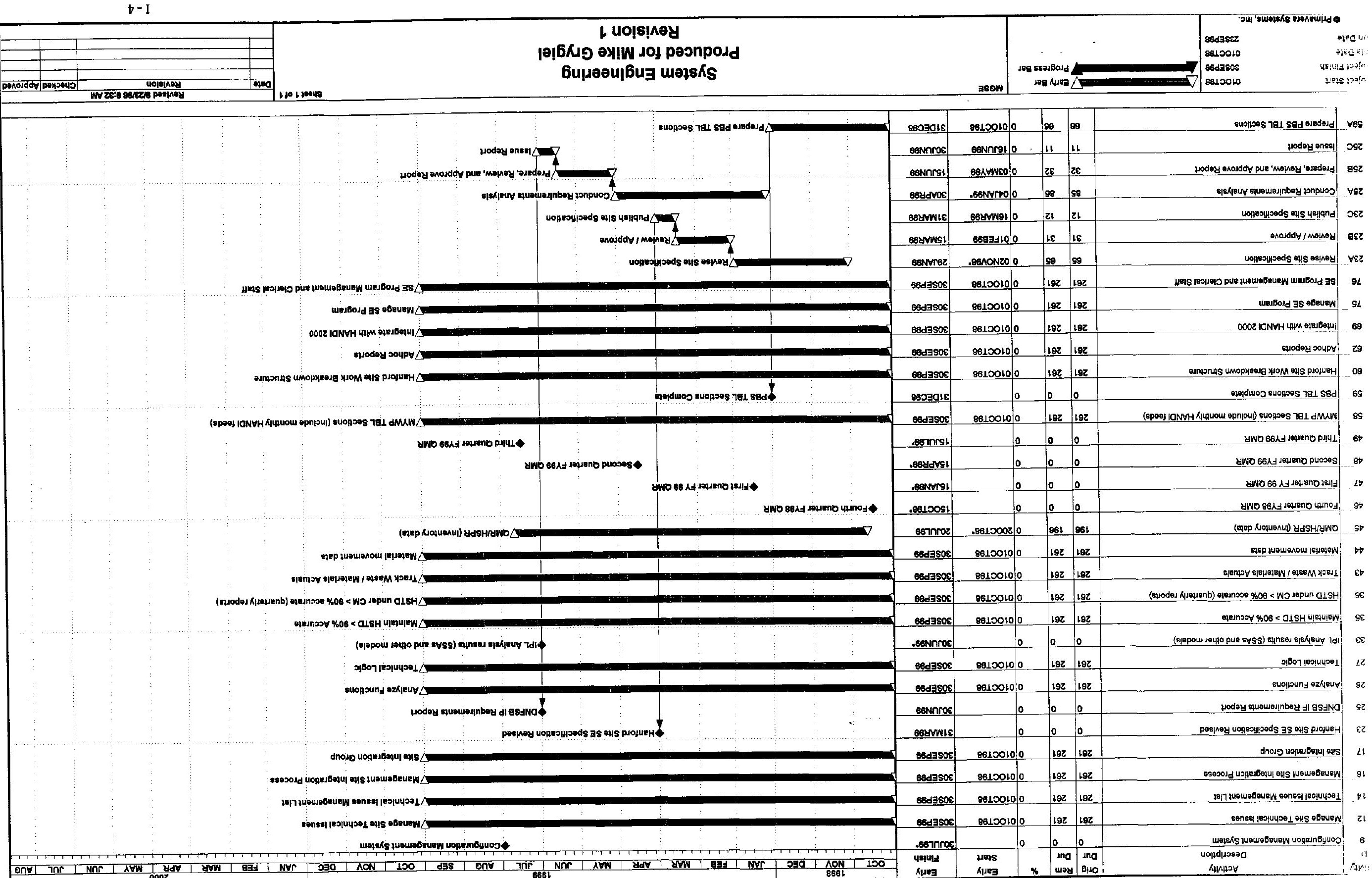




\subsection{COST BASELINE}

\subsection{ESTIMATE BASIS}

The basis of estimate for this project was arrived at using the principles of Activity Based Costing $(A B C)$ in which the project was segmented into discrete supporting activities. Costs were assigned to specific cost elements based on historical use patterns (trends), published rate tables, and escalation rate of 2.2 percent that are consistent with those developed by the FDH Chief Financial Officer and approved by the DOE-RL.

Cost estimates for FY 1999 were prepared at the task level or lower. Cost estimates for FY 2000 were prepared at the cost account level using the escalation rate of 2.1 percent and for the out years were prepared at the cost account level using the escalation rate of 2.2 percent compounded.

\subsection{SUMMARY OF LIFE CYCLE COSTS BASELINE (BCWS) BY PROJECT} See Exhibit 1.

\subsection{SUMMARY OF LIFE CYCLE BUDGET AUTH ORITY (B/A) BY PROJECT}

See Exhibit 4.

4.4 COST BASELINE (BCWS) FOR EXECUTION YEAR BY MONTH BY FUND TYPE To be provided at a later date.

\subsection{COST BASELINE (BCWS) FOR EXECUTION BY MONTH BY RESOURCE TYPE}

To be provided at a later date. 


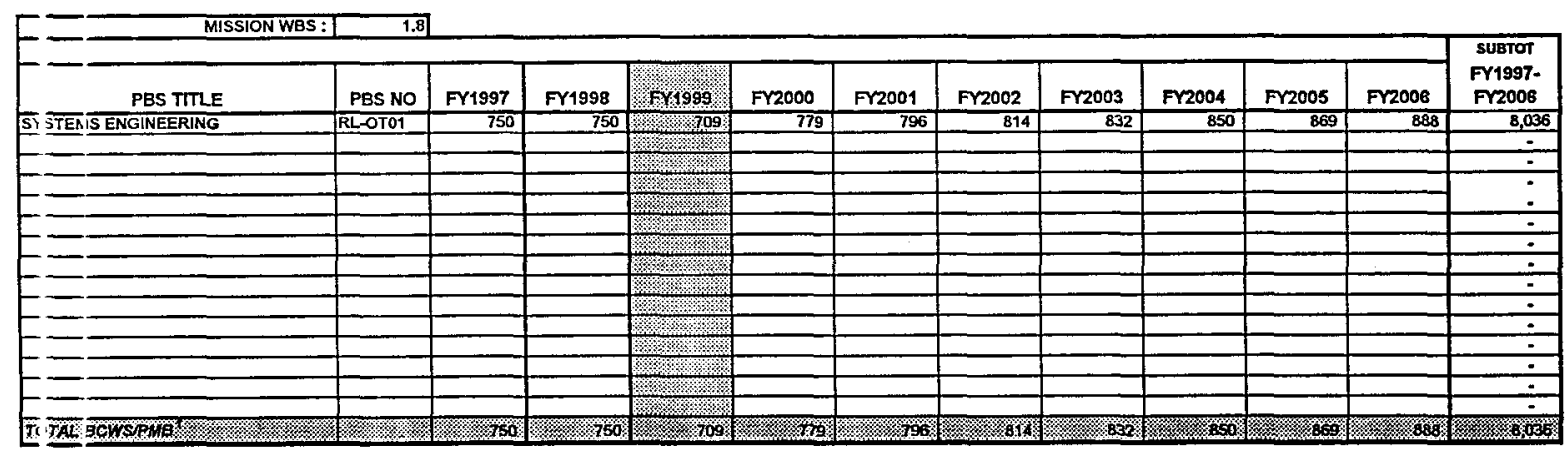

'Budgeted Cost of Work Scheduled (BCWS) Equals Performance Measurement Baseline (PMB); Expense Carryover Is NOT Included. 


\begin{tabular}{|c|c|c|c|c|c|c|c|c|c|c|c|c|c|c|}
\hline \multicolumn{14}{|c|}{ MISSION WBS: 1.8} & \multirow{2}{*}{$\begin{array}{l}\text { TOTAL } \\
\text { FY1997- } \\
\text { FY2050 } \\
\end{array}$} \\
\hline PBS TITLE & PBS NO & FY2007 & Fr2008 & FY2009 & FY2010 & $\begin{array}{l}\text { FY2011- } \\
\text { FY2015 }\end{array}$ & $\begin{array}{l}\text { FY2016- } \\
\text { FY2020 }\end{array}$ & $\begin{array}{l}\text { FY2021- } \\
\text { FY2025 }\end{array}$ & $\begin{array}{l}\text { FY2026- } \\
\text { FY2030 }\end{array}$ & $\begin{array}{l}\text { FY2031- } \\
\text { FY2035 }\end{array}$ & $\begin{array}{l}\text { FY2036 } \\
\text { FY2040 }\end{array}$ & $\begin{array}{l}\text { FY2041- } \\
\text { FY2045 }\end{array}$ & $\begin{array}{l}\text { Fr2046 } \\
\text { FY2050 }\end{array}$ & \\
\hline SYSTEMS ENGINEERING & RL-OTOI & 907 & 927 & 948 & 968 & 5,179 & 5,766 & 6,428 & 7,167 & 7,991 & 8,910 & 9,934 & 11,076 & 74,228 \\
\hline & & & & & & & & & & & & & & - \\
\hline & & & & & & & & & & & & & & - \\
\hline & & & & & & & & & & & & & & - \\
\hline & & & & & 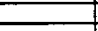 & & $\rightarrow$ & - & & & & & & - \\
\hline & & & & & & & & & & & & & & $\div$ \\
\hline & & & & & & & & & & & & & & $\div$ \\
\hline & & & & & & & & & & & & & & $\div$ \\
\hline & & & & & & & & & & & & & & - \\
\hline & & & & & & & & & & & & & & $\div$ \\
\hline & & & & & & & & & & & & & & - \\
\hline POTAY ECKSTRMA: & & , 907 & $92 \pi$ & 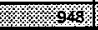 & 968 & S, & S & 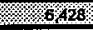 & $\frac{1}{316}$ & (20993 & 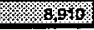 & 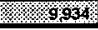 & 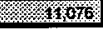 & 24223 \\
\hline
\end{tabular}

'Budgeted 1Budgeted Cost of Work Scheduled (BCWS) Equals Performance Measurement Baseline (PMB); Expense Carnyover la NOT Included. 


\section{SUPPORT \\ SUMMARY OF BUDGET AUTHORITY (B/A) BY YEAR \\ BY PROJECT BASELINE SUMMARY (PBS) \\ FY 1999 \\ (\$000s)}

\begin{tabular}{|c|c|c|c|c|c|}
\hline MISSION WBS: & 1.8 & & & & \\
\hline & & \multirow{2}{*}{$\begin{array}{l}\text { TARGET } \\
\text { B/A } \\
\text { FY1998 }\end{array}$} & \multirow{2}{*}{$\begin{array}{l}\text { CARRYOVER } \\
\text { FROM } \\
\text { FY1998 }\end{array}$} & \multirow{2}{*}{$\begin{array}{l}\text { PRESIDENIS' } \\
\text { BUDGET } \\
.1 \% 1999\end{array}$} & \multirow{2}{*}{ 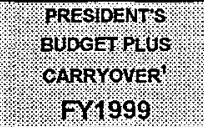 } \\
\hline PBS TITLE & PBS NO & & & & \\
\hline \multirow[t]{15}{*}{ SYSTEMS ENGINEERING } & RL-OT01 & 750 & - & 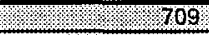 & 1709 \\
\hline & & & & 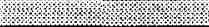 & V \\
\hline & & & & (3) & (5) \\
\hline & & & & 落: & 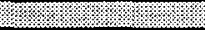 \\
\hline & & & & W & S) \\
\hline & & & & 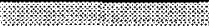 & 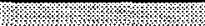 \\
\hline & & & & 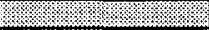 & (2) \\
\hline & & & & (3) & l. \\
\hline & & & & (1) & l) \\
\hline & & & & 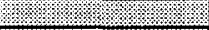 & $e_{1}$ \\
\hline & & & & 等: & 等: \\
\hline & & & & 桨: & צ' \\
\hline & & & & (4) & 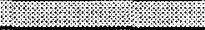 \\
\hline & & & & (5. & \%: \\
\hline & & & & (3) & (4) \\
\hline TOTAL B/A & & 750 & 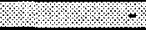 & 709 & 6.709 \\
\hline
\end{tabular}

'Estimated Carnyover Is NOT Inciuded In Cost Baseline; Change Request For Actual Carryover Submitted After September 30, 1998. 


\section{PROJECT BASELINE SUMMARIES (PBS) LEVEL}

\subsection{TECHNICAL BASELINE}

\subsection{PROJECT MISSION STATEMENT}

See summary in Section I for this information.

\subsection{PROJECT END POINT TARGETS}

Project end point targets do not apply to this activity.

\subsection{MAJOR FACILITIES}

The major facility concept does not apply to this activity.

\subsection{DRIVERS}

Project Management Hanford Contract

PHMC, Section C.2, Management and Integration Workscope

Part A - Site Planning

Part B - Management Systems

Management and Integration Plan (HNF MP-001 Rev. 1)

RLID 430.1, Systems Engineering Criteria Document and Implementing Directive

RLPD 430.1, Hanford Site Systems Engineering Policy

Hanford Federal Facility Agreement and Consent Order (Tri-Party Agreement)

OMB: Recommend use of systems engineering to resolve integration problems.

DNFSB 92-4 recommended using systems engineering to resolve integration problems.

DOE Standard 1073-93

Hanford Strategic Plan, DOElRL-96-92

Hanford Site Environmental Management Specification, DOELRL-97-55 (Revision 1)

Fluor Daniel Hanford Systems Engineering Management Plan (HNF-MP-007) 


\subsection{WORK BREAKDOWN STRUCTURE (WBS)}

\subsection{WBS HIERARCHY}

See next page. 


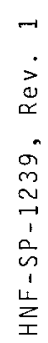

궁
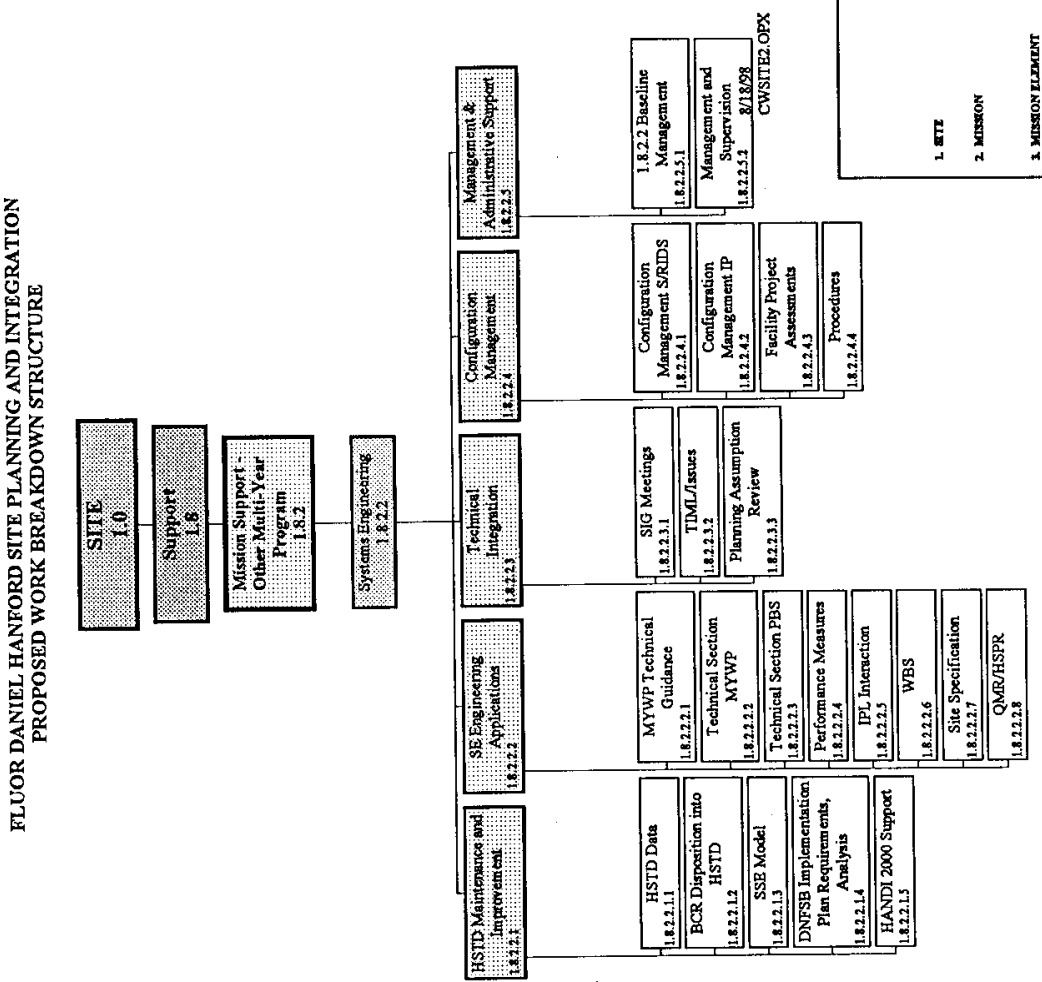

$\stackrel{m}{\square}$

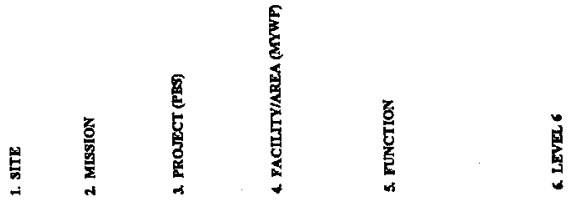




\subsection{WBS DICTIONARY}

2.2.1 HSTD Maintenance and Improvement

\begin{tabular}{|l|l|l|l|}
\hline $\begin{array}{l}\text { 1. Dictionary Title: } \\
\text { HSTD Maintenance and } \\
\text { Improvement }\end{array}$ & 2. Date: & 3. PBS Number: & 4. Dict Rev: \\
\hline $\begin{array}{l}\text { 5. WBS No.: } \\
\text { 1.8.2.2.1 }\end{array}$ & $\begin{array}{l}\text { 6. B\&R No.: } \\
\text { EW3110010 }\end{array}$ & 7. Baseline CR No.: \\
\hline
\end{tabular}

8. Organization Name: Site Planning \& Integration

9. Scope of Work:

\section{ELEMENT TASK DESCRIPTION -}

Site Systems Engineering, in accordance with the PHMC, and in accordance with RLID 430.1, is responsible for producing and maintaining a Hanford Site Technical Database (HSTD). This technical data covers the Environmental Management technical work performed on the Hanford Site. It is developed by Site Systems Engineering and the projects, and supported by the tools and methods used by Systems Engineers. Data residing in the HSTD is used to validate the site cleanup system, identify technical issues for resolution where problems exist in the HSTD data, and to drive the projects' work planning process.

CONTENT/WORK STATEMENT -

709k Level - 4.60 FTE

Maintain and Improve the HSTD

1. Ensure that the FY 1999 data are maintained current in the HSTD. This includes incorporation of TWRS privatization changes when agreed upon. Also includes routine incorporation of changes to the HSTD resulting from approved BCRs.

2. Maintain site systems analyses for TWRS, SNF, WM, ER, and FS/ART current to support change request validation. Complete systems analysis models including validation and approval by user organizations for PNNL and Infrastructure by January 30, 1999.

3. Conduct a requirements analysis of DNFSB implementation plans for Hanford and integrate with the HSTD by June 30, 1999.

4. Provide development support and data to ensure that HANDI 2000 is compatible with the HSTD data structure and processes.

5. Maintain HSTD quality above $90 \%$ using quantitative metrics similar to those used in 1998 . 


\subsubsection{Systems Engineering Applications}

\begin{tabular}{|l|l|l|l|}
\hline $\begin{array}{l}\text { 1. Dictionary Title: } \\
\text { Systems Engineering } \\
\text { Applications }\end{array}$ & 2. Date: & 3. PBS Number: & 4. Dict Rev: \\
\hline $\begin{array}{l}\text { 5. WBS No.: } \\
1.8 .2 .2 .2\end{array}$ & $\begin{array}{l}\text { 6. B\&R No.: } \\
\text { EW3110010 }\end{array}$ & 7. Baseline CR No.: \\
\hline
\end{tabular}

8. Organization Name: Site Planning \& Integration

9. Scope of Work:

\section{ELEMENT TASK DESCRIPTION -}

Site Systems Engineering, in accordance with the PHMC, and in accordance with RLID 430.1, is responsible for providing the technical basis for the integrated site baseline and its associated planning and reporting products. The technical baseline which provides this basis is housed in the Hanford Site Technical Database (HSTD). The data is used to produce the products and provide the support described below.

CONTENT/WORK STATEMENT -

709k Level - 1.4 FTE

SE Applications

1. Support planning products for management of FY 1999 activities and development of FY 2000 ISB.

Maintenance of Hanford Site EM Specification

Guidance for preparation of FY 2000 MYWP technical sections

Technical sections of FY 2000 MYWPs

Support IPL development

Technical sections of PBSs

Strategic planning analyses

Ad hoc support requests for data/reports

Align performance metrics in MYWP, PBS, and QMR. HSPR consistent with HSTD QMR/HSPR performance metrics 
2.2.3 Technical Integration

\begin{tabular}{|l|l|l|l|}
\hline $\begin{array}{l}\text { 1. Dictionary Title: } \\
\text { Technical Integration }\end{array}$ & 2. Date: & 3. PBS Number: & 4. Dict Rev: \\
\hline $\begin{array}{l}\text { 5. WBS No.: } \\
\text { 1.8.2.2.3 }\end{array}$ & $\begin{array}{l}\text { 6. B\&R No.: } \\
\text { EW3110010 }\end{array}$ & 7. Baseline CR No.: \\
\hline
\end{tabular}

8. Organization Name: Site Planning \& Integration

9. Scope of Work:

ELEMENT TASK DESCRIPTION -

Site Systems Engineering, in accordance with the PHMC, and in accordance with RLID 430.1, provides the forum for discussion and approval of integration related activities, products, and issues. This forum is the Site Integration Group (SIG). The SIG is attended by DOE and contractor representatives from the EM mission activities at Hanford. One of the key areas addressed by the SIG is technical integration issues which are contained in the Technical Issues Management List (TIML).

CONTENT/WORK STATEMENT -

709k Level - 0.50 FTE

\section{Technical Integration}

1. Conduct Site Integration Group (SIG) meetings.

2. Maintain the Technical Issues Management List (TIML) and coordinate actions of ad hoc teams. Issue a quarterly status report on TIML including issues closed, new issues added, issues being actively worked, and issues with no activity during the reporting period.

3. Issue TIML monthly when changes occur.

4. Ensure issues arising from the SSAs are assigned and addressed appropriately.

5. Review and approve planning assumptions in the Site EM Specification. 
2.2.4 Systems Engineering Configuration Management

\begin{tabular}{|l|l|l|l|}
\hline $\begin{array}{l}\text { 1. Dictionary Title: } \\
\text { Systems Engineering } \\
\text { Configuration Mgmt. }\end{array}$ & 2. Date: & 3. PBS Number: & 4. Dict Rev: \\
\hline $\begin{array}{l}\text { 5. WBS No.: } \\
\text { 1.8.2.2.4 }\end{array}$ & $\begin{array}{l}\text { 6. B\&R No.: } \\
\text { EW3110010 }\end{array}$ & 7. Baseline CR No.: \\
\hline
\end{tabular}

8. Organization Name: Site Planning \& Integration

9. Scope of Work:

ELEMENT TASK DESCRIPTION -

Per the PHMC, the contractor shall "establish a configuration management system based on industry consensus standards, which is integrated with other management tools, such as change control, and assures a sound technical basis of the Integrated Site Baseline." Site Systems Engineering will continue to implement, improve and integrate the PHMC configuration management system through out the PHMC contractor team.

\section{CONTENT/WORK STATEMENT -}

\section{9k Level - 0 FTE (Anticipated Funding is at 0.75 FTE Level)}

The focus of activities for FY99 will build on the implementation activities of FY97 (PHMC CM Plan) and FY98 (Major Project CM Implementation Plans and Essential Drawing metrics). For this year, the focus will be to evaluate CM implementation through out the PHMC team. Combined project reviews will be held to evaluate $\mathrm{CM}$ implementation in the major projects and to share best practices. CM training practices will be determined and evaluated. Essential drawing metrics that were baselined in FY98 will continue to be reported and improvements will be made. Procedures, relevant to $\mathrm{CM}$, will be updated as necessary to improve integration of $\mathrm{CM}$ activities.

Deliverables:

1. Reports on combined project reviews that evaluate how $\mathrm{CM}$ requirements are implemented in the major projects. Evaluation of how the CM training is conducted and configuration identification will be included.

2. For the essential drawing metrics, established in FY98, improvement targets will be determined and the metrics will be tracked.

3. Updates will be made to the PHMC CMP and CMIP.

4. Other procedures will be written to connect the PHMC CMP requirements to implementing procedures across the PHMC team.

The following deliverables have less importance and would be added if funding allows.

5. Configuration status accounting and configuration identification database will be developed.

6. Advocate and investigate integration and standardization of $\mathrm{CM}$ implementation across FDH and including BHI, BMI, BNFL, JCI and HAMMER.

7. Training and travel. 
2.2.5 Management and Administration Support

\begin{tabular}{|l|l|l|l|}
\hline $\begin{array}{l}\text { 1. Dictionary Title: } \\
\text { Management and } \\
\text { Administration } \\
\text { Support }\end{array}$ & 2. Date: & 3. PBS Number: & 4. Dict Rev: \\
\hline $\begin{array}{l}\text { 5. WBS No.: } \\
1.8 .2 .2 .5\end{array}$ & $\begin{array}{l}\text { 6. B\&R No.: } \\
\text { EW3110010 }\end{array}$ & 7. Baseline CR No.: \\
\hline
\end{tabular}

8. Organization Name: Site Planning \& Integration

9. Scope of Work:

\section{ELEMENT TASK DESCRIPTION -}

To maximize efficiency and encourage communications across function, the Project Management support function consolidates managerial and administrative functions in a uniform activity. It consolidates management oversight, secretarial support, departmental administrative duties, special projects, and planning.

CONTENT/WORK STATEMENT -

\section{9k Level -1.00 FTE}

1. Projects/RL interface - Ongoing dialogue with Project Management as part of SSE's mandate to ensure horizontal integration of baselined workscope, i.e., integration of across projects. This activity also comprises those activities needed to keep RL-PMD and other RL parties apprised of status, issues, and accomplishments.

2. Departmental planning and oversight - Provides forward thinking direction necessary to accomplish organizational goal as they support the site mission. RL required deliverable specific to this function such as the MYWP, PBS, monthly spending forecast, PTS report, etc., are performed under Project Management.

3. Personnel training and development - Assess current capabilities relative to future needs; develops corresponding personnel development plans to ensure the organization can respond to the demands associated with completing its mission.

4. Special Projects - Provides limited resources to respond to anticipated, but yet to be defined, initiative connected with, and necessary to achieve planned work scope.

5. Secretarial support - Provides the secretarial/clerical network needed to support departmental functions. 


\section{Deliverables}

1. Monthly spending forecast/project status report processing

2. PBS

3. Quarterly RL briefing of project status

4. Draft MYWP Section 1 (confirm $90 \%$ database accuracy)

5. Final MYWP Section 1 (confirm $90 \%$ database accuracy)

6. TIML (except when no changes occur)

7. TIML Status Report

\section{Due Date}

Seven days following performance

TBD

11 January 1999

12 April 1999 (mid-year)

12 July 1999

12 October 1999 (year-end)

*30 July 1999

*27 August 1999

Monthly

Quarterly 


\subsection{RESPONSIBILITY ASSIGNMENT MATRIX (RAM)}

See Figure 2.3, Responsibility Assignment Matrix.

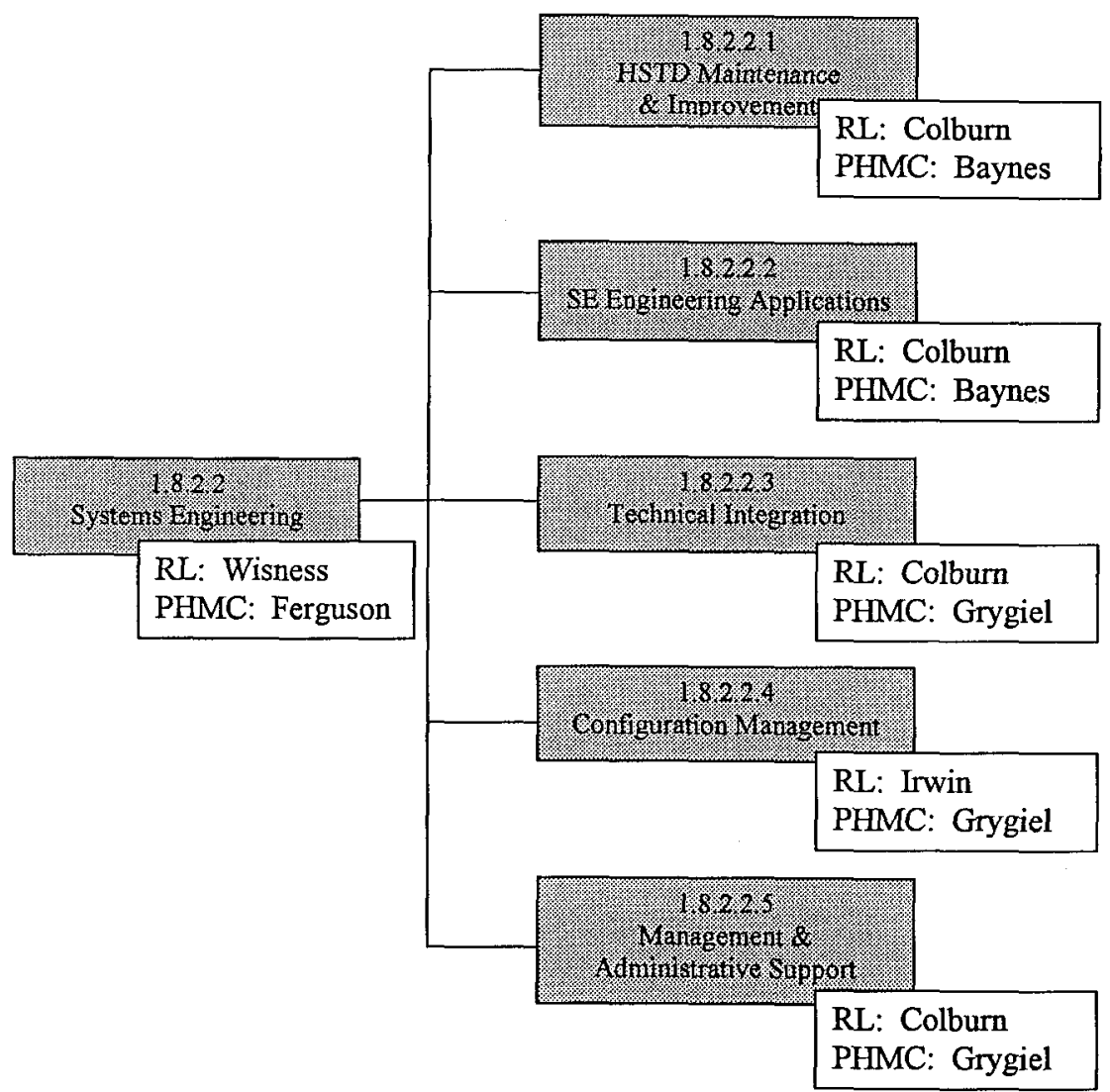

Figure 2.3. Responsibility Assignment Matrix (RAM) 


\subsection{SCHEDULE BASELINE}

\subsection{PROJECT MASTER BASELINE SCHEDULE (PMBS) BY PBS}

See Part I, Section 3.0 for this information.

\subsection{EXECUTION YEAR PMBS}

See Part I, Section 3.0 for this information.

\subsection{MLESTONE LIST (DOE-HQ, RL,FO)}

\begin{tabular}{|c|c|c|c|c|c|c|}
\hline $\begin{array}{l}\text { Milestone } \\
\text { Control }\end{array}$ & $\begin{array}{l}\text { MS } \\
\text { Level }\end{array}$ & MS Title & Type & $\begin{array}{l}\text { Planned } \\
\text { Baseline }\end{array}$ & T1P & $\mathrm{PBS} \%$ \\
\hline HST-99-001 & RL & $\begin{array}{l}\text { Maintain and Improve the Hanford Site } \\
\text { Technical Database }\end{array}$ & OTH & $5 / 31 / 99$ & $\overline{\mathrm{N}}$ & RL-OT01 \\
\hline HST-99-002 & RL & $\begin{array}{l}\text { Requirements Analysis of DNFSB } \\
\text { Implementation Plans }\end{array}$ & OTH & $6 / 30 / 99$ & $\overline{\mathbf{N}}$ & RL-OT01 \\
\hline SEA-99-001 & $\mathbf{R L}$ & Systems Engineering Application & OTH & $7 / 31 / 99$ & $\mathbf{N}$ & RL-OT01 \\
\hline CMA-99-001 & RL & $\begin{array}{l}\text { Configuration Management Consolidated } \\
\text { Program Review }\end{array}$ & OTH & $7 / 31 / 99$ & $\mathbf{N}$ & RL-OT01 \\
\hline CMA-99-002 & $\mathrm{RL}$ & Drawing Metrics & OTH & $3 / 31 / 99$ & $\mathbf{N}$ & RL-OT01 \\
\hline
\end{tabular}

\subsection{MILESTONE DESCRIPTION SHEETS (MDS)}




\section{PHMC \\ MILESTONE DESCRIPTION SHEET}

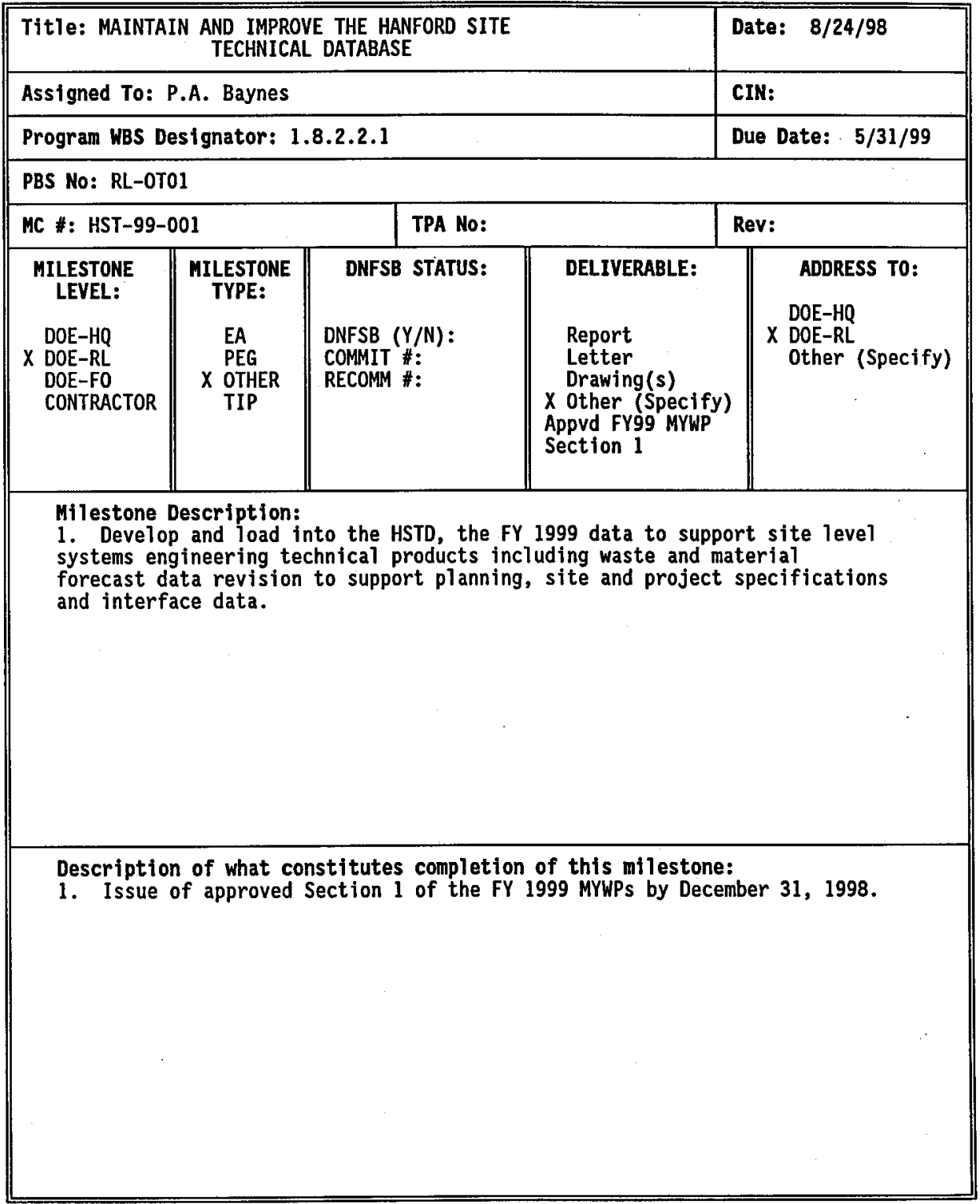




\section{PHMC \\ MILESTONE DESCRIPTION SHEET}

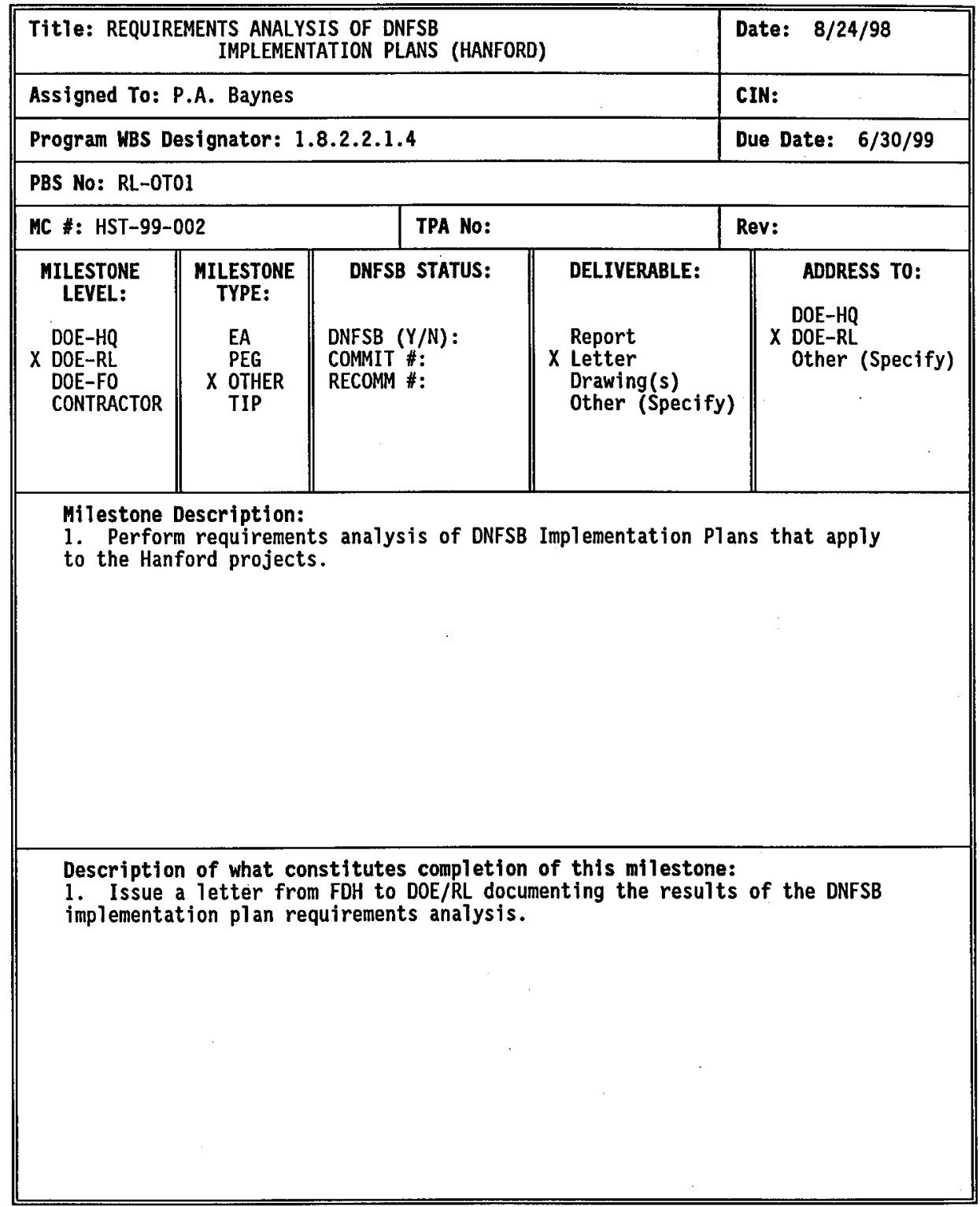




\section{PHMC}

MILESTONE DESCRIPTION SHEET

\begin{tabular}{|c|c|c|c|c|}
\hline \multicolumn{4}{|c|}{ Title: SYSTEMS ENGINEERING APPLICATION } & Date: $8 / 24 / 98$ \\
\hline \multicolumn{4}{|c|}{ Assigned To: P.A. Baynes } & CIN: \\
\hline \multicolumn{4}{|c|}{ Program WBS Designator: 1.8 .2 .2 .2} & Due Date: $7 / 31 / 99$ \\
\hline \multicolumn{5}{|c|}{ PBS No: RL-0T01 } \\
\hline \multicolumn{2}{|c|}{ MC \#: SEA-99-001 } & TPA No: & & Rev: \\
\hline $\begin{array}{l}\text { MILESTONE } \\
\text { LEVEL: } \\
\text { DOE-HQ } \\
\times \text { DOE-RL } \\
\text { DOE-FO } \\
\text { CONTRACTOR }\end{array}$ & $\begin{array}{l}\text { MILESTONE } \\
\text { TYPE: } \\
\text { EA } \\
\text { PEG } \\
\times \text { OTHER } \\
\text { TIP }\end{array}$ & $\begin{array}{l}\text { DNFSB STATUS: } \\
\text { DNFSB }(Y / N): \\
\text { COMMIT \#: } \\
\text { RECOMM \#: }\end{array}$ & $\begin{array}{l}\text { DELIVERABLE: } \\
\text { Report } \\
\text { Letter } \\
\text { Drawing (s) } \\
\text { X Other (Specify) } \\
\text { Tech Sections- } \\
\text { FY2000 PBS, MYWP }\end{array}$ & $\begin{array}{l}\text { ADDRESS TO: } \\
\text { DOE-HQ } \\
\times \text { DOE-RL } \\
\text { Other (Specify) }\end{array}$ \\
\hline \multicolumn{5}{|c|}{$\begin{array}{l}\text { Milestone Description: } \\
\text { 1. Interface with Project Directors, provide support and use existing Site } \\
\text { Systems Analysis to support baseline analysis and produce support planning } \\
\text { products from the HSTD. Those products are guidance for MYWP preparation, } \\
\text { Technical Sections of MYWP and PBS. }\end{array}$} \\
\hline \multicolumn{5}{|c|}{$\begin{array}{l}\text { Description of what constitutes completion of this milestone: } \\
1 . \text { Issue draft FY } 2000 \text { MYWP Section } 1 \text { based on Mission Planning Guidance } \\
\text { in accordance with agreed upon schedule guidance from DOE/RL. } \\
2 \text {. Issue Technical Sections for the FY } 2000 \text { Project Breakdown Structure } \\
\text { and Multi-Year Work Plans in accordance with schedule guidance from DOE/RL. }\end{array}$} \\
\hline
\end{tabular}




\section{PHMC \\ MILESTONE DESCRIPTION SHEET}

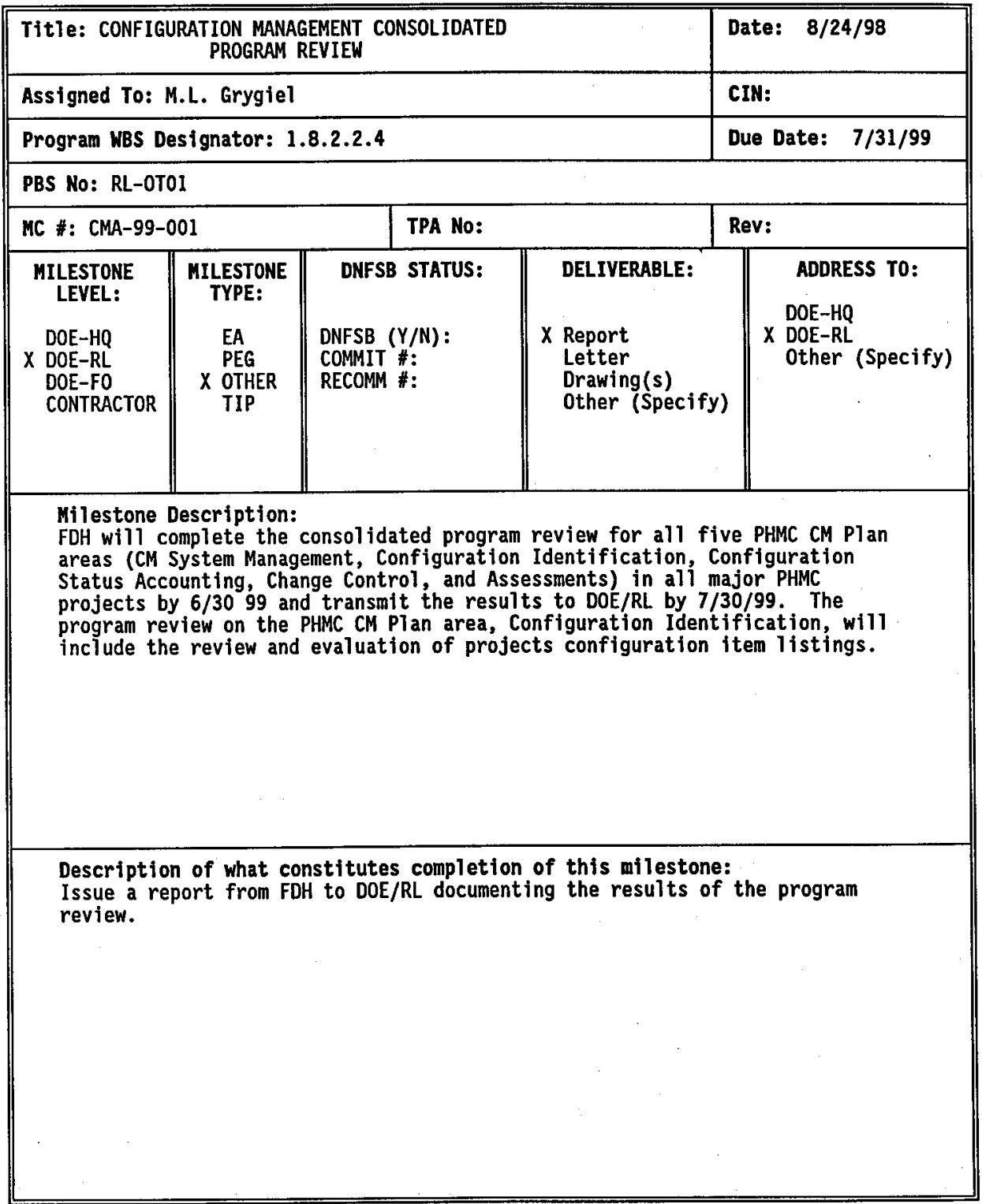




\section{PHMC}

MILESTONE DESCRIPTION SHEET

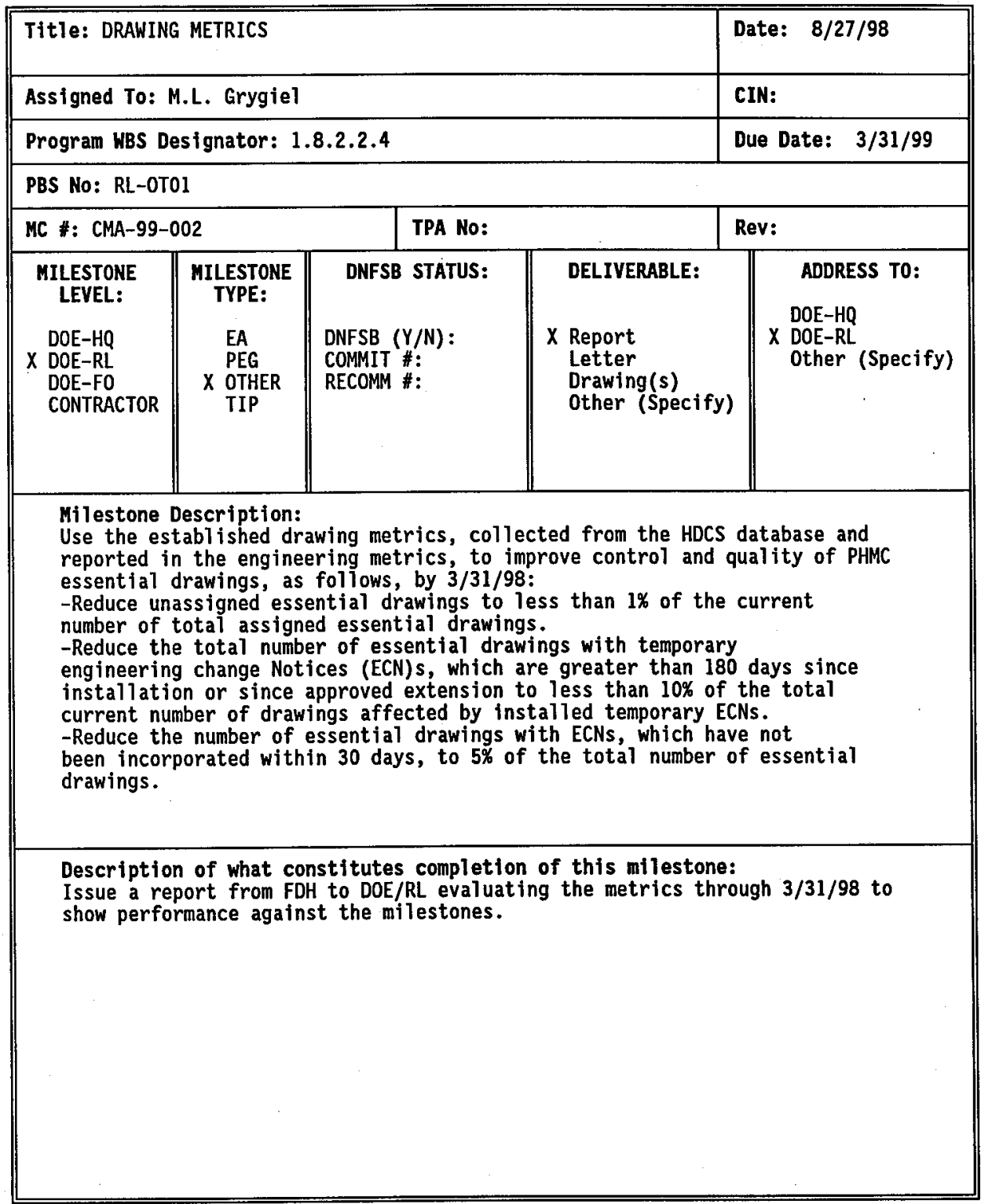




\subsection{COST BASELINE}

\subsection{LIFE CYCLE COST BASELINE (BCWS) BY PBS}

See Exhibit la.

\subsection{LIFE CYCLE BUDGET AUTHORITY (B/A) BY PBS}

See Exhibit 4a.

\subsection{EXECUTION YEAR COST BASELINE BY MONTH BY PBS BY FUND TYPE}

To be provided at a later date. 
BY PROJECT BASELINE SUMMARY (PBS)

FY 1999

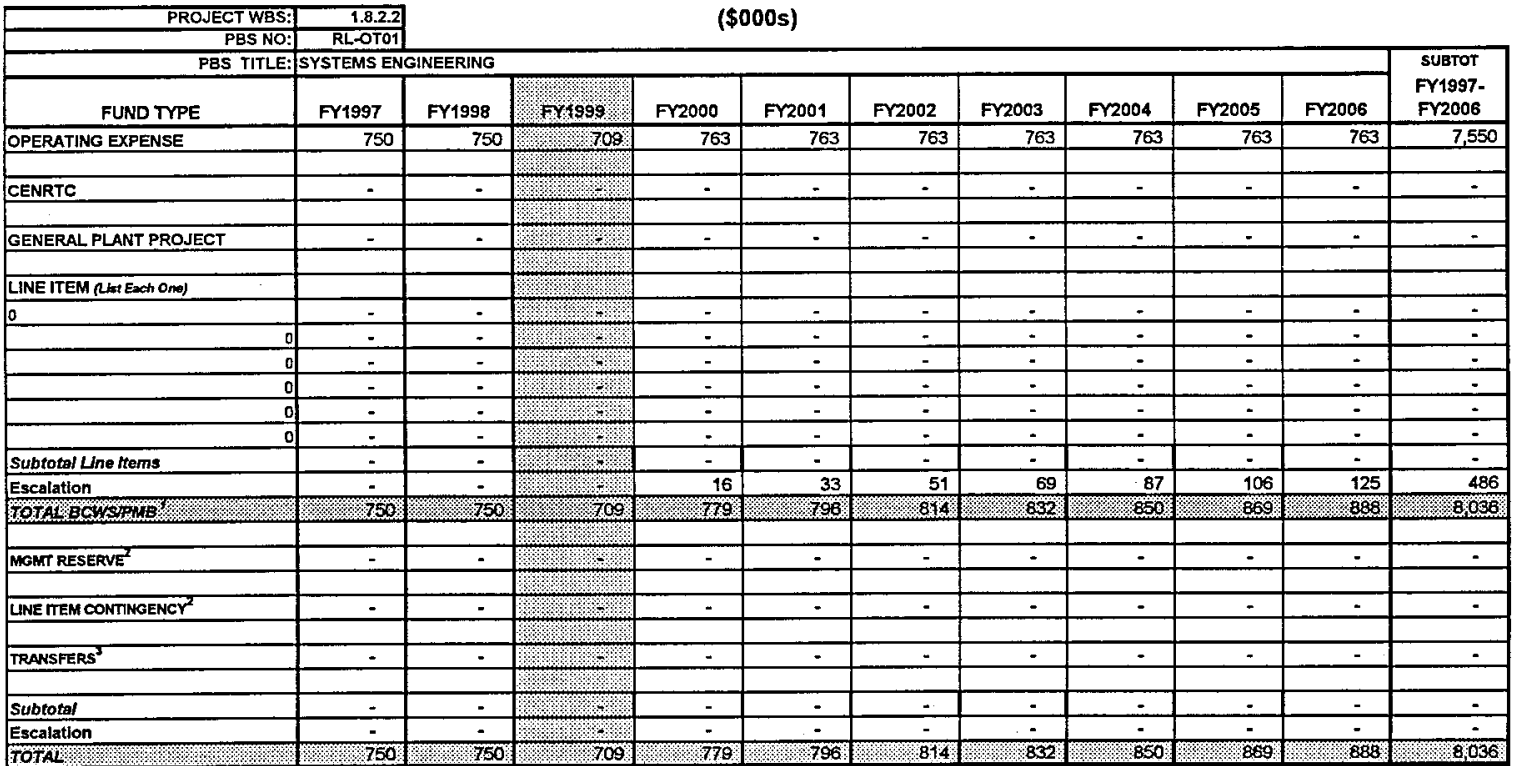

'Budgeted Cost of Work Scheduled (BCWS) Equals Performance Measurement Baseline (PMB); Expense Carryover is Not Included

'Management Reserve and Line Hem Contingency Held By RL.

'Funds/Workscope Transferred to Other Sites, Transferred to Hianford from Other Sites, and/or Funds/Workscope Controlled by RL. 
BY PROJECT BASELINE SUMMARY (PBS)

FY 1999

PROJECT WBS: $\quad \mathbf{1 . 8 . 2 . 2}$

(\$000s)

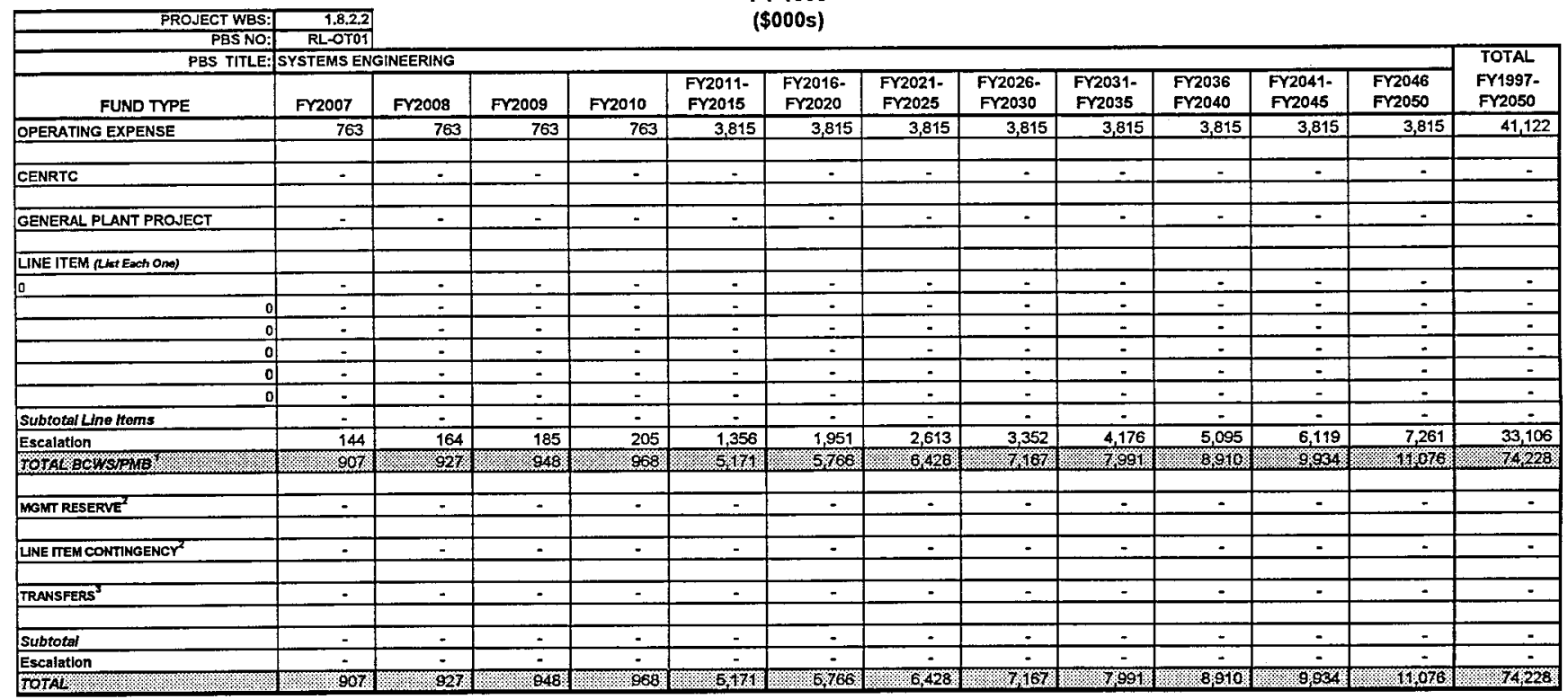

'Budgeted Cost of Work Scheduled (BCWS) Equals Performance Measurement Baseline (PMB); Expense Carryover ts Not ineluded

'FundsWorkscope Transferred to Other Sites, Transferred to Hanford from Other Sites, and/or FundeWorkscope Controlled by RL. 


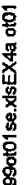

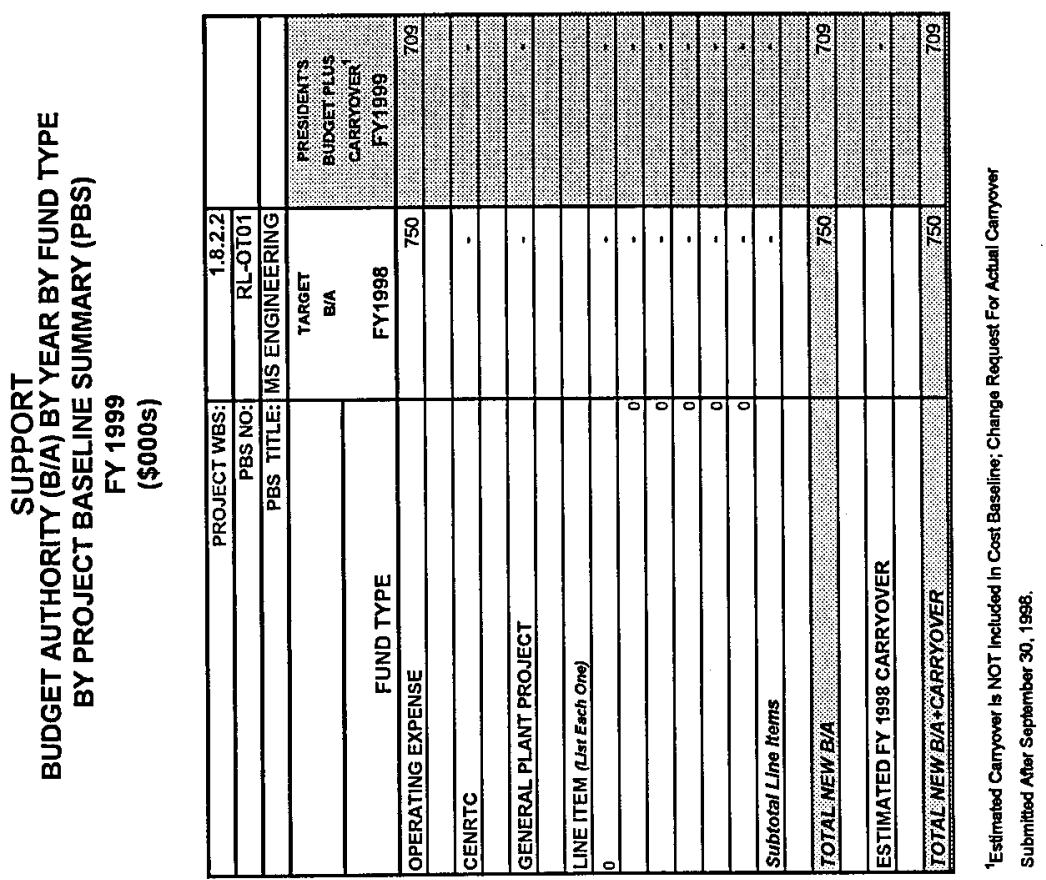




\section{ADDITIONAL REQUIREMENTS}

\subsection{SPECIAL TPA REPORT}

TPA milestones do not apply to this activity.

\subsection{PROJECT PRIORITY LIST}
1. HSTD Maintenance and Improvement
1.8.2.2.1
$\$ 448,000$
2. Systems Engineering Applications
1.8.2.2.2
$\$ 126,000$
3. Technical Integration
1.8.2.2.3
$\$ 45,000$
4. Management and Administrative Support
1.8.2.2.5
$\$ 90,000$
5. Configuration Management
1.8.2.2.4

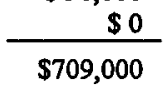

\subsection{PERFORMANCE ENHANCEMENTS}

Performance enhancements do not apply to this activity.

\subsection{PERFORMANCE OBJECTIVES AND MEASU RES}

See attachment at the end of Section III.

\subsection{MYWP UPDATE SUMMARY}

Summary of Proposed Updates to the Site Planning and Integration 1.8.2.2 FY 1999 MYWP

PBS Number and Title - The following changes have been made from FY 1998 to FY 1999. Configuration management has been deleted from this WBS and is now covered under another PBS area. Effort has been added to cover the technical support provided in the development of the MYWP and PBS packages as well as tracking and providing technical performance data for various reports. Additional effort has been added to technical analysis in support of change control and effort has been covered for continued support of the Site EM Specification.

Outcomes - The major impact of these changes involves funding for requested work that was not funded in FY 1998.

Technical - No change in technical requirements or scope will result from this work except those resulting from the baseline change control process.

Schedule - These changes will not result in changes to the schedule baseline except those resulting from the baseline change control process. No changes to the 1,8.2.1 PBS schedule.

Cost - Impact will be the need for additional funding to cover requested work within the 1.8.2.1 PBS element. 
Funding - Based on available funding, scope will be adjusted by deleting or scaling down requested work. Impact to site life cycle planning will be minimal. The decision support tool and risk profiles will not be taken to the full production level.

Key Areas of Focused Emphasis:

a. Performance Objectives and Performance Metrics - As work is agreed upon with DOE based on available funding, objectives and metrics will be finalized.

b. Performance enhancements - None

c. TIML - N/A

d. TIPS - N/A 


\section{Performance Objectives and Measures}

\section{Systems Engineering}

\begin{tabular}{|c|c|c|c|c|c|c|c|c|}
\hline $\begin{array}{l}\text { HSP Success Indicatori } \\
\text { Critical Success Factor }\end{array}$ & Strategic Outcome/Goal & Performance Objective & Output/Metric & $\begin{array}{l}\text { EM } \\
\text { Management }\end{array}$ & FY 1999 & 12000 & FY 2001 FY 97-06 & $\begin{array}{l}\text { End Point } \\
\text { Target }\end{array}$ \\
\hline $\begin{array}{l}\text { OTO1-SE } \\
\text { Manage Hanford to } \\
\text { achieve progress }\end{array}$ & $\begin{array}{l}\text { Projectize Hanford for } \\
\text { clear management } \\
\text { accountability, } \\
\text { responsibility and authority }\end{array}$ & $\begin{array}{l}\text { Implement/maintain a high } \\
\text { level integrated systems } \\
\text { engineering process that } \\
\text { maintains Site data under } \\
\text { configuration management } \\
\text { inciuding requirements, } \\
\text { assumptions, waste data, } \\
\text { interfaces, material forecasts, } \\
\text { infrastructure needs \& issues } \\
\text { management }\end{array}$ & $\begin{array}{l}\text { Perform requirements analysis of } \\
\text { DNFSB implementation plans } \\
\text { applicable to Hanford projects }\end{array}$ & $\begin{array}{l}\text { No } \\
06 / 30 / 1999\end{array}$ & & & . & ' \\
\hline . & & . & $\begin{array}{l}\text { Maintain and improve the HSTD; } \\
\text { issue approved Section } 1 \text { of the } \\
\text { MYWPs }\end{array}$ & $\begin{array}{l}\text { No } \\
05 / 31 / 1999\end{array}$ & & & & \\
\hline 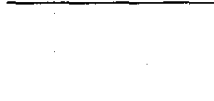 & & & $\begin{array}{l}\text { Complete the consolidated } \\
\text { program review for all } 5 \text { PHMC } \\
\text { configuration management plan } \\
\text { areas }\end{array}$ & $\begin{array}{l}\text { No } \\
07 / 31 / 1999\end{array}$ & 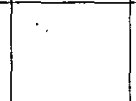 & & & \\
\hline & . & & $\begin{array}{l}\text { Support baseline analysis and } \\
\text { planning products (MYWPIPBS) } \\
\text { from the HSTD }\end{array}$ & $\begin{array}{l}\text { No } \\
07 / 31 / 1999\end{array}$ & & & . & \\
\hline$\cdot$ & & & $\begin{array}{l}\text { Use established drawing metrics to } \\
\text { improve control and quality of } \\
\text { specified PHMC essential drawings }\end{array}$ & $\begin{array}{l}\text { No } \\
03 / 31 / 1999\end{array}$ & & & & \\
\hline 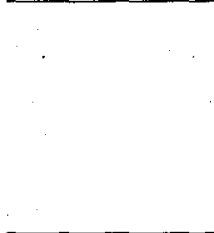 & $\begin{array}{l}\text { Maintain financial and } \\
\text { managerial control }\end{array}$ & $\begin{array}{l}\text { Implement/maintain a high } \\
\text { level integrated systems } \\
\text { engineering process that } \\
\text { maintains Site data under } \\
\text { configuration mgmt including } \\
\text { requirements, assumptions, } \\
\text { waste data, interfaces, } \\
\text { material forecasts, } \\
\text { infrastructure needs \& issues } \\
\text { management }\end{array}$ & $\begin{array}{l}\text { Control cost/schedule variance: } \\
\text { WBS 1.8.2.2 cost/schedule } \\
\text { performance is within established } \\
\text { thresholds }\end{array}$ & $\begin{array}{l}\text { No } \\
09 / 30 / 1999\end{array}$ & $\begin{array}{l}-5 \mathrm{CV} /- \\
7.5 \% \mathrm{SV}\end{array}$ & $\begin{array}{l}-5 \mathrm{CV} / \\
7.5 \% \mathrm{~S}\end{array}$ & $\begin{array}{r}-5 \mathrm{CV} /- \\
7.5 \% \mathrm{~S}\end{array}$ & \\
\hline
\end{tabular}




\section{CORRESPONDENCE DISTRIBUTION COVERSHEET}

Author

M. L. Grygiel
Addressee

Distribution
Correspondence No.

Subject: Site Systems Engineering Fiscal Year 1999 Multi-year Work Plan (MYWP) Update for WBS 1.8.2.2

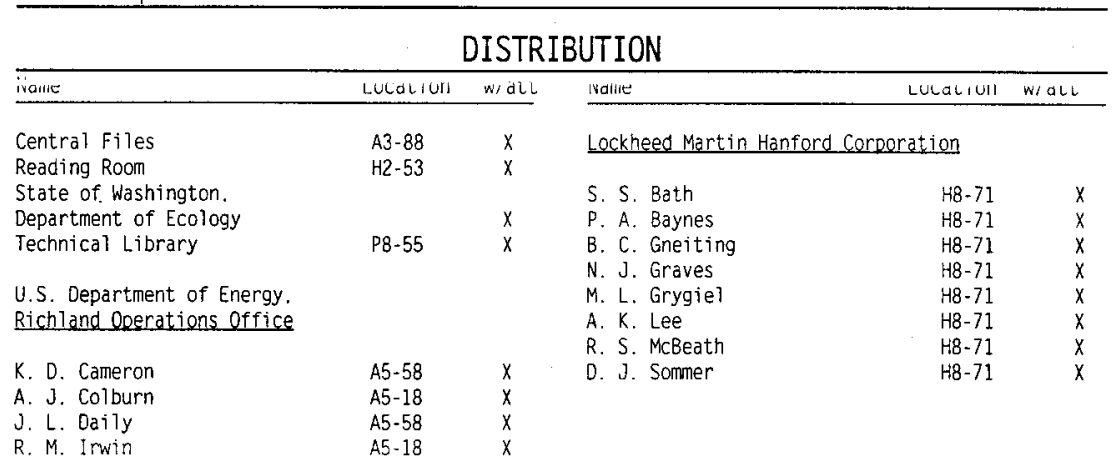

Fluor Daniel Hanford. Inc.

R. B. Agee

K. A. Bence

R. M. Brackett

C. Edwards

L. R. Hafer

L. E. Maiden

G. J. McCleary

R. M. Pielstick

B. A. Reichmuth

W. M. Ritter

E. A. Schultz

J. L. Waite

A. J. Watts
B3-53

B3. 53

B3-53

B3 -53

B3 -53

B3-53

B3-53

B3-53

B3-53

B3 -53

B3-53

B3-53

B3-53
P. A. Baynes

B. C. Gneiting

N. J. Graves

Grygie

K. Lee

R. S. McBeath

D. J. Sommer
$48-7$

H8-71

$48-71$

H8-71

H8-71

$18-71$ 